\title{
Negative side effects of customer integration
}

\section{Oliver Gassmann}

Institute of Technology Management, University of St. Gallen,

Dufourstrasse 40a, CH-9000 St. Gallen, Switzerland

E-mail: oliver.gassmann@unisg.ch

\section{Christoph Kausch}

Etzelblickstrasse 1, CH-8834 Schindellegi

E-mail: christoph@kausch.eu

\section{Ellen Enkel*}

Dr. Manfred Bischoff Institute of Innovation Management of EADS, Zeppelin University, Am Seemoser Horn 20,

D- 88045, Friedrichshafen

E-mail: ellen.enkel@zeppelin-university.de

${ }^{*}$ Corresponding author

\begin{abstract}
Customer integration has many recognised advantages, but also entails negative side effects that may impair the success of innovative activities. These negative side effects have not yet been sufficiently investigated. Whereas some may occur within the entire early innovation phase, others are likely to affect only few sub-phases. Each sub-phase, defined in a slightly new way as compared with existing models to meet the investigation subject, has different activities and aims, and therefore requires special integration methods and customer types. On the basis of extensive research and empirical studies, the paper illustrates different integration methods, negative effects of customer integration, and measures to avoid them.
\end{abstract}

Keywords: customer integration; early innovation phase; negative (side) effects.

Reference to this paper should be made as follows: Gassmann, O., Kausch, C. and Enkel, E. (2010) 'Negative side effects of customer integration', Int. J. Technology Management, Vol. 50, No. 1, pp.43-62.

Biographical notes: Oliver Gassmann is Professor of Technology Management at the University of St. Gallen, Switzerland and Director of the Institute of Technology Management. After completing his PhD in 1996, he was leading research and advanced development of Schindler Corporation, headquartered in Ebikon, Switzerland. He published in leading journals such as Research Policy, R\&D Management, International Journal of Technology Management, IEEE Transactions on Engineering Management, Harvard Business Manager. At the core of his research is the pervading question of how companies innovate and profit from innovation. Thus, he is dedicated to discovering new approaches to the management of technology and innovation that contribute to firms' competitive advantage. 
Christoph Kausch is currently an Engagement Manager at an international management consulting company in Zurich. His focus is on Operations and Supply Chain Management. After finishing his Master Degree in Mechanical Engineering at the Technical University of Munich and Massachusetts Institute of Technology, he completed his $\mathrm{PhD}$ in Innovation Management at the University of St. Gallen's Institute of Technology Management and Harvard Business School.

Ellen Enkel is Professor of Innovation Management and Head of the Dr. Manfred Bischoff Institute of Innovation Management of EADS at the Zeppelin University in Friedrichshafen, Germany. Before she was heading the competence centre Open Innovation at the Institute of Technology Management at the University of St. Gallen (Switzerland). Her research interests focus on cooperative innovation processes like open and cross-industry innovation, innovation networks within and across companies as well as innovation metrics systems. She has a broad industry experience working with companies like Daimler, Unilever, IBM, BASF, Alcan and Henkel and has published four books and several academic articles in the area of innovation and technology management.

\section{Customer integration and negative side effects}

Innovations are essential for securing and expanding a company's position in the market (Larson, 2001). In times of decreasing R\&D budgets and shorter innovation cycles, companies have to integrate external innovation sources (Gassmann and Enkel, 2004). One trigger for customer integration is the high failure rate of innovative products (Atuahene-Gima, 1995). Customer integration can reduce this rate: customers know what they want and need and thus guarantee that new products developed accordingly will satisfy the market. At the same time, customers constitute a reliable buyer potential. In addition, early customer integration minimises the risk of a change having to be made later to meet customers' wishes and accordingly prevents the increase in costs and the reduction of profits that a delayed market introduction causes (Atuahene-Gima, 1995; Bacon and Beckman, 1994; Kohli and Jaworski, 1990; Murphy and Kumar, 1996, 1997).

These recognised positive effects of customer integration have led to the almost general consensus that customer knowledge is an indispensable prerequisite for a successful early innovation phase. However, growing experience with customer integration has shown that the involvement of customers, advantageous as it is, also entails negative side effects, such as dependence on customers or loss of know-how among other unwelcome aspects (Enkel et al., 2005; Veryzer, 1998). So far, neither theory nor practice has provided recommendations on how to avoid or suppress undesired side effects.

\section{Customer integration in the fuzzy front end}

The early innovation phase is the first of three consecutive phases within the entire innovation process; the other two phases are technical product development and commercialisation. This first phase is the optimal starting point for customer integration, 
having the biggest impact on R\&D activities (Koen et al., 2001). It is also called 'upfront', "front end of innovation", or, increasingly, "fuzzy front end" (Kim and Wilemon, 2002; Koen et al., 2001), and covers the period from the very first identification of innovation opportunities to the final definition of a concept that is ready for development (Cooper and Kleinschmidt, 1986; Khurana and Rosenthal, 1997; Kim and Wilemon, 2002; Koen et al., 2001; Tidd and Bodley, 2002). As the epithet 'fuzzy' indicates, this phase is anything but strictly organised and structured. The seeming semi-chaos is necessary and intended to bring about an atmosphere conducive to creative ideas. However, 'fuzzy' does not mean that there is no structure whatever; sufficient results cannot be gained without some organisation (Buggie, 2002). To combine flexibility and freedom of innovative investigation with a checkable course of data flow, Koen $(2001,2002)$ developed a model of the fuzzy front end, the New Concept Development (NCD) Model, which subdivides the early innovation phase into five sub-phases. In this model, the diverse sub-phases are not strictly separated, but interact with the others, influencing them and being influenced in turn. The model is arranged in a circle that symbolises the free circulation and (up to a point) flexible sequence of the sub-phases, whereas other models, e.g., the Stage Gate Process with its strictly separated and distinct phases (Cooper and Kleinschmidt, 1986; Dwyer and Mellor, 1991; McGuiness and Conway, 1989) do not allow an interaction. Our data analysis suggests a modification of this model with regard to customer integration. While the construction of an iterative model with different sub-phases is useful, the case studies show that a different subdivision (opportunity identification and analysis, idea and knowledge creation, idea and functionality selection, concept definition, and prototype testing) represents corporate activities best (see Figure 1).

Each sub-phase requires different competencies and knowledge from both customers and company because its focus is on specific outcomes. Consequently, when analysing the negative side effects of customer integration, we have to differentiate between the respective sub-phases. These are characterised here:

Figure 1 The fuzzy front end with regard to integrating customer knowledge (see online version for colours)

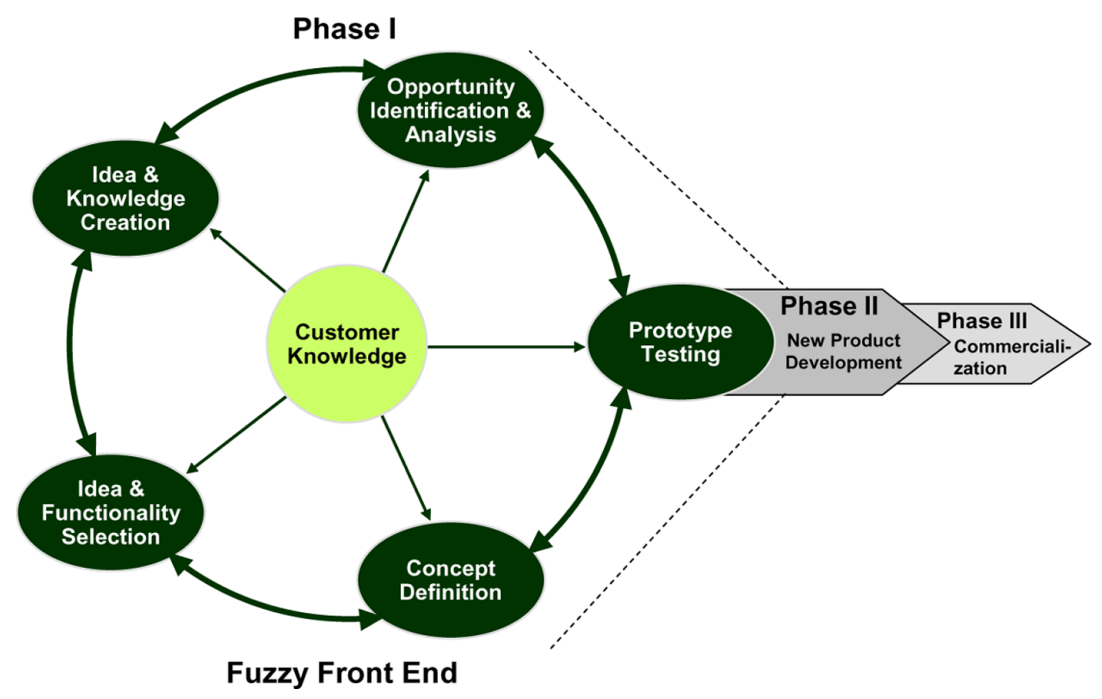




\subsection{Opportunity identification and analysis}

In this sub-phase, the company searches for and analyses opportunities (e.g., new innovation fields, trends to follow) to be pursued later, opportunity meaning a business or technical need that a company may wish to satisfy to gain a competitive advantage (Koen et al., 2002).

In the identification part, various established tools and methods of business intelligence help identify existing opportunities (roadmapping, scenario planning, etc.). The analysis part entails the evaluation of the identified opportunities, examining which of them are worth pursuing. The opportunities are examined and graded according to their attractiveness, development potential, and fit with the company's strategy and culture. The final assessment also largely depends on the decision-makers' risk tolerance because many uncertainties still remain.

As with opportunity identification, opportunity analysis is either part of a formal process, or occurs iteratively. Many tools of the identification process are also used in this part, but to another end: they now have to provide an answer regarding the future pursuit of the identified opportunities. An additional and highly recommended practice is the assignment of a multifunctional team, working full time on the analysis and consisting of three to five company members with at least one marketing and one R\&D member (Koen et al., 2002).

\subsection{Idea and knowledge creation}

This sub-phase, which is a combination of Koen's idea generation element and the newly developed knowledge creation sub-phase suggested by our data and research, centres on finding ideas for a new product while gathering pertinent or general knowledge. Ideas presuppose knowledge; on the other hand, new knowledge is gained through ideas. The core competencies of technology and knowledge - internal and external, implicit and explicit - enable a company to fall back on a reservoir of scientific and practical know-how if and when the need arises. The process of tossing up, turning around, modifying, discussing and finally shaping ideas that characterises the creation of innovative ideas (Koen et al., 2002) brings with it a certain amount of surplus knowledge for future use. Creating ideas therefore entails using as well as creating knowledge that has to be gathered in a structured way. This sub-phase feeds and is fed by the other sub-phases to a much higher degree than the interaction among them.

The foremost techniques of idea creation include the established creativity and brainstorming methods (brainstorming, brainwriting, method 635, mind-mapping, synectic methods) as well as the Russian TRIZ system (the theory of inventive problem solving (Altshuller, 1988), which induces people to leave their own special field of science and to enter other scientific areas to find new solutions to the problem at hand.

Knowledge creation's tools and methods comprise the usual means of gathering information: patent research, congresses, bibliography, workshops with experts on selected technical or scientific problems, and so on, combined with the widely established intranet and data bank systems. 


\subsection{Idea and functionality selection}

In this sub-phase, the company decides which ideas and functionalities compiled in the previous phase ought to be pursued. This decision may be vital for a company's success or failure. Koen et al. (2002) point out that a formal decision process that allocates business resources to new ideas, provides the originators of the ideas with feedback, and establishes an innovation culture facilitating this selection. The usual financial measurements, such as cash flow calculations, sales and profit forecasts, and net present value considerations, are also helpful, but more for incremental than for breakthrough ideas.

\subsection{Concept definition}

This element of the early innovation phase consists of drawing up a business or technology proposition for the envisaged product. This business plan is the 'gate document' and is necessary to allow an idea to enter the product development phase (Koen et al., 2002). Diverse evaluation criteria for this permission, such as innovativeness, fit with product strategy, market potential, time to market, demand for resources, possibility of substitution, synergies within the company, product uniqueness, technical feasibility etc. have been established (Cooper and Kleinschmidt, 1994; Hart et al., 2003; Linton et al., 2002; Meade and Presley, 2002).

\subsection{Prototype testing}

Strictly speaking, prototype testing belongs to the development phase but bears some similarities with the early innovation phase with regard to customer integration.

Before a new product goes into serial production, it is tested in the form of few specimens to find out if the new ideas work in practice. Possible negative experiences with the prototype model lead to a change at a time when this can still be done without too much waste of time and money.

\section{Customer integration methods in the various sub-phases}

Integrating customers requires certain activities on the company's side that comprise the selection and actual inclusion of customers as co-innovators. Customers can be involved in the innovation process with various methods, each specifically suited to the respective purpose. Some apply to all sub-phases and all kinds of customers; others are best suited to particular sub-phases or customers and will be discussed in the context of the respective empirical findings.

Various customer integration methods have been used. The Lead User approach (Herstatt and von Hippel, 1992; Lilien et al., 2002; Olson and Bakke, 2001; Urban and von Hippel, 1988; von Hippel, 1986, 1988; von Hippel et al., 1999), based on the selection and integration of visionary opinion leaders, is one of the best established customer integration methods. The User Toolkit method enables customers to configure parts of or complete products by means of special toolkits (Franke and Piller, 2004; Franke and von Hippel, 2002; Thomke and von Hippel, 2002; von Hippel and Katz, 2002). With the help of the Empathic Design method, introduced 
by Leonard-Barton (1995), customers are watched while using existing products to draw conclusions about as yet unexpressed needs or wishes (Leonard and Rayport, 1997; Leonard and Sensiper, 1998; Ulwick, 2002). In this way, as with conventional market research, information is gained without actively involving customers. The concept of focus groups, developed by Calder (1977), is by now a widespread method of customer integration as well (see also Bruseberg and McDonagh-Philp, 2002; McQuarrie and McIntyre, 1986).

Each integration method needs different customer types to be most effective. Herstatt and von Hippel (1992) distinguish two groups of customers: normal ones and lead users. Lead users have special needs, profit more than others from the desired innovative product, and perceive trends very early. Brockhoff (2003), concentrating on forms and ways of customer input, discerns five types of customers:

- the 'demanding' customer, i.e., the representative of the demand side of the market, who expresses his needs either directly or by his behaviour and thus supplies new ideas

- the 'launching' customer, who actively takes part in market introduction

- the 'innovative' customer whose own, almost completed, innovative solutions to his problems form the basis of a new product

- the 'reference' customer, who passes on his experience of using a certain product to the producer or to other users/customers

- the 'first buyer', who helps reduce uncertainties about market expectations within the company.

Each customer type has different knowledge and competencies and thus can provide different input to the respective sub-phase.

\section{Negative side effects of customer integration}

The integration of customers in these five sub-phases can have negative side effects. The word effect refers to a phenomenon that is produced by an agent or cause. In the context of cause and effect, we speak of a side effect when the occurrence of a result as a consequence of a certain cause is not intended, but happens to arise together with or instead of the desired result. With regard to customer integration, a desired result would, for example, be better market orientation, whereas a side effect could be a resulting dependence on customers. Such negative side effects do not have to occur, but may do so; because of this uncertainty, they are often referred to as risks.

With the focus on customer integration in the early innovation phase as described in our model, we formulate the following hypothesis:

Hypothesis: Each customer integration activity in the different sub-phases will have related negative side effects. 


\section{Research methodology and data sample}

We chose individual companies' R\&D organisation as our unit of analysis. For each organisation, our research followed three principal steps. First, we sought to determine the extent of customer integration. Second, we examined which customer types are integrated in which sub-phase of the fuzzy front end. Third, we investigated the negative side effects related to the identified customer integration activities.

Different types of data were needed in each step, and different data collection methods were used to ensure the quality and accuracy of subsequent data analysis. As a first step, R\&D locations were identified by means of company publications and third-party R\&D databases.

To determine which R\&D units actively integrate customer, we developed a questionnaire focusing on the intensity of customer integration activities in terms of the number of activities, the value created by them, related problems, and the management's view of further investment in customer integration. The questionnaire was sent to R\&D directors and senior R\&D managers. In some companies, we were also able to collect data through interviews during workshops and R\&D project meetings.

In total, we received data from 141 companies.

Combined with internal documentation on $R \& D$ organisation, presentations by R\&D personnel, and memos from R\&D managers, these semi-structured data helped us (in a second step) select 18 companies for in-depth case studies. We targeted international companies in science and technology-intensive industries (see Table 1), since these industries rank among the highest in terms of average $R \& D$ to sales ratio. The chosen companies investigate their customer integration activities and the negative side effects related to these activities very closely. We conducted a total of 126 interviews using a semi-structured interview guideline, made several site visits to each company, and had access to internal documents. Finally, we reported our findings to the interviewed companies and sought their feedback to correct possibly erroneous interpretations.

Table 1 Company sample: industry, size, and turnover

\begin{tabular}{|c|c|c|c|}
\hline Company name & Industry affiliation & $\begin{array}{l}\text { Number of } \\
\text { employees }\end{array}$ & $\begin{array}{l}\text { Turnover in } \\
\text { million } €\end{array}$ \\
\hline AUDI & Car manufacturer & 53.089 & 24.500 \\
\hline BAYER & Pharmaceuticals & 115.400 & 28.567 \\
\hline BMW & Car manufacturer & 104.342 & 41.525 \\
\hline GETZNER & $\begin{array}{l}\text { Foamed polyurethane } \\
\text { elastomers }\end{array}$ & 145 & 26 \\
\hline HENKEL & Consumer goods & 48.328 & 9.436 \\
\hline IBM & $\begin{array}{l}\text { Information } \\
\text { technologies }\end{array}$ & 319.273 & 71.934 \\
\hline INFOTERRA & $\begin{array}{l}\text { Geo-information } \\
\text { solutions }\end{array}$ & 200 & 6 \\
\hline $\mathrm{KABA}$ & Security systems & 5900 & 998.3 \\
\hline MERCK & Pharmaceuticals & 28.877 & 5.859 \\
\hline MICROSOFT & Software solutions & 57.086 & 27.462 \\
\hline SCHINDLER & $\begin{array}{l}\text { Conveyance of } \\
\text { passengers }\end{array}$ & 39.617 & 7.725 \\
\hline
\end{tabular}


Table 1 Company sample: industry, size, and turnover (continued)

\begin{tabular}{llcc}
\hline Company name & Industry affiliation & $\begin{array}{c}\text { Number of } \\
\text { employees }\end{array}$ & $\begin{array}{c}\text { Turnover in } \\
\text { million } €\end{array}$ \\
\hline SCHURTER & $\begin{array}{l}\text { Electronic and } \\
\text { electrical engineering }\end{array}$ & 1000 & 100 \\
SEFAR & $\begin{array}{l}\text { Screen printing and } \\
\text { filtration solutions }\end{array}$ & 1.600 & 200 \\
SIEMENS & Automation and control & 430.000 & 75.167 \\
SIG & Packaging equipment & 6.671 & 1.694 \\
SULZER HEXIS & Fuel cell systems & (SIG HOLDING) & (SIG HOLDING) \\
ZF FRIEDRICHSHAFEN & Automotive supplier & 9.586 & 1.335 \\
ZUMTOBEL STAFF & Lighting solutions & 53.500 & 8.900 \\
& & 7.643 & $1.142,2$ \\
& & (ZUMTOBEL & (ZUMTOBEL \\
\hline
\end{tabular}

The questionnaire survey was carried out between October 2003 and February 2004, the case studies and feedback rounds were conducted between February and November 2004.

The case study data were analysed according to the model presented in the previous section. To focus on the new aspect - negative side effects related to customer integration activities - we illustrated these activities through examples. In the following passages, the pertinent empirical findings are compiled and discussed.

\section{Findings: customer integration and its negative side effects}

The empirical findings start with new insights on which particular integration methods among those listed in the Literature Review above are best suited for the different sub-phases and which individual methods companies have developed and adopted. In a second part, the discovered negative side effects together with the respective reducing measures will be described jointly to avoid repetition; it will, however, be pointed out in which sub-phases these effects are most likely to occur. A table with each sub-phase's characteristics, integration methods, side effects, and recommended measures to reduce them will summarise the findings section.

\subsection{Examples of applied customer integration methods in the various sub-phases}

With opportunity identification, customers are often integrated via intermediaries. Key account managers or developers usually receive detailed information from their customers about their experiences with a product. These customers are mostly lead users, but not necessarily so. Their feedback is an important means of opportunity identification. SIEMENS integrates customers through a centralised key account management. The customers' input is transferred via strategy meetings and inner strategic circles to the R\&D planners. GETZNER WERKSTOFFE maintains a close relationship with their customers through their sales agents and key account managers. 
The company's goals and developments are thoroughly discussed with the customers and their input is transferred directly into the company.

Lead users are also invited to take part in the special workshops that characterise this period, mainly in business intelligence workshops for roadmapping, scenario planning, and trend analysis. SEFAR (a market leader in filtration systems) integrates lead users in special workshops to identify and analyse opportunities. With the help of an analogous lead user approach adapted to the company's resources, lead users in other market segments are selected and interviewed.

With regard to identifying lead users, our research has produced several ways beyond the established ones (Herstatt and von Hippel, 1992), starting with a collection of criteria that indicate the 'right' lead users:

In respect of the envisaged product, the prospective integrated customer should be either a trendsetter or a market leader. The customer's reputation (in case the customer is a company and not an individual) in the market is also very important, as are his PR and sales potential for presenting and, in some cases, even selling off the result of the collaboration with the public. Other criteria are the customer's competence, complementary skills, and interests. The recognition of these criteria presupposes a former (positive) collaboration experience with the respective customer, a criterion that was deemed especially significant. Not all criteria are equally important; each company has to heed those that are suited to the specific integration project.

As far as finding lead users who meet these criteria is concerned, trade fairs, sales conferences, and focus groups offer possibilities to get to know them. In addition, seminars are a good way to identify lead users. GETZNER WERKSTOFFE frequently organises scientific seminars on sylomer elastomers with major rail companies, engineering companies, and universities where all the participants present new technologies and major trends. This helps them find appropriate co-developers, besides giving an insight into their competitors' and customers' activities.

Apart from lead users, demanding and reference customers are included in this sub-phase. They mostly provide their input passively via market research. Another way is to watch them - if possible, secretly - using existing products before experts analyse their behaviour. This is the integration concept of the Empathic Design method. SCHURTER, a manufacturer of fuses and connectors, uses this method on a large scale, thus often identifying new opportunities.

Reference customers integrated in conventional market research are mostly picked out at random. Newly developed IT-based tools open up new possibilities of reaching customers. Interactive games, placed on the internet, siphon off customers' needs. However, this 'information pump' (Dahan and Hauser, 2001) requires skill and creativity on the part of the person who installs the specific internet platform.

With opportunity analysis, customer integration, apart from the inclusion of lead users in workshops, consists of inviting special customers as temporary members of the multifunctional team. ZF FRIEDRICHSHAFEN, a tier one automotive supplier, invites different customers to such meetings. Through its interaction with the customers, the company gains valuable insights on the identified opportunities.

The permanent inclusion of customers within the multifunctional team is not advisable because the aim of this phase is not in all respects suited to external participation (e.g., fit with the company's strategy). 
With idea and knowledge creation, the methods and tools mentioned in the sub-phase description almost cry out for the integration of lead users whose above-average knowledge and experience make them ideal sparring partners for company experts when generating ideas.

Customer integration can take place in workshops with experts, but also by an extension of the company's internal data collection system. Our empirical research reveals the usage of web-based idea banks - not only for company employees, but also for customers, preferably lead users, via their respective linkages. A well-known example is BMW's 'Virtual Innovation Agency' that gathers feedback and ideas from external sources. Employees access this web-based idea bank through intranet pages.

IT-based tools - opinion portals, online communities - and special toolkits (Thomke and von Hippel, 2002) are designed to enable lead users and launching customers to contribute innovative suggestions and, incidentally, knowledge. The choice of these customers is influenced by the way the toolkit is programmed to reach hitherto unknown interested customers. The anonymity of this method overcomes the customers' possible shyness or reticence to articulate their needs, wishes, and suggestions.

BMW's marketing innovation lab follows a three-step approach in which customers' ideas, arriving via their website and by way of customer e-mails, are used to select trend-setting and technically capable lead users. In the next step, these customers are confronted with an idea, e.g., the functionalities of the human-machine interface in a future BMW series, and are asked to develop their own relevant ideas that are followed up in mixed workshops. The third step belongs to the idea and functionality selection phase.

Our research reveals additional ways and possibilities of gaining customer knowledge during the idea creation sub-phase:

- $\quad$ specialist/technical fairs

- focus groups

- co-branding

- sales conferences

- conjoint analysis

- partner meetings

Feedback via key account managers or developers with direct contact to customers complements the means of customer integration at this point of the innovation process. Some companies have developed individual ways of cooperating with customers. BAYER Material Science integrates customers into a special 'creative centre' that was established with the purpose of co-creating innovations with customers. SIEMENS appoints lead users to managers of core technology units within the central department of corporate technology.

Idea and functionality selection, in contrast, is more or less a company's own business. This is confirmed by the BMW Group whose innovation lab discusses the compiled external ideas and suggestions internally and selects the most valuable ones without any other input at all by itself. It may, however, be feasible and, in some 
instances, advisable to let a few carefully selected customers choose among competing pre-selected ideas, because their preference is important for future market success.

In the concept definition sub-phase, customer integration is rare, too. INFOTERRA, a subsidiary of EADS, is one of the few companies to integrate demanding and launching customers as well as lead users and first buyers into the development of the business plan. If customers are integrated, they should be lead users, reference customers, or first buyers. Workshops with customers on a special topic (for example, GETZNER'S workshop on the dampening attributes of sylomer) may be useful to develop a more detailed concept of a product idea. To this end, GETZNER also gives lectures on the topic to reference customers and first buyers and uses the input of the following discussions for concept improvements.

Customer integration methods in prototype testing largely depend on the product to be tested. Empathic Design methods and beta-testing (testing by the customers on their own) are more frequent than alpha-testing (customers testing the product at the company's site together with employees).

The integrated customers are mostly lead users, prospective first buyers, or launching customers. SULZER HEXIS carried out an international 3-year testing period with beta testers. Their input led to the further development and improvement of new fuel cells. BMW Group relies on testing prototypes of new cars not only with special company test drivers but also with lead users and reference customers.

\subsection{Negative side effects and how to avoid them}

The side effects described here, which are all established in theory, were confirmed in the course of our investigation.

\subsubsection{Dependence on customers' views or interests}

A customer's point of view influences the direction of the search for innovative ideas (Gruner and Homburg, 2000; Wynstra and Pierick, 2000). The external point of view, welcome as it is, may bias the direction of the search in an unwelcome way, which is illustrated by the following examples: ZUMTOBEL STAFF, a global market leader in electronic light technology, integrates renowned architects and light designers into its early innovation phase. Their unusual and highbrow solutions, while meeting the highest aesthetic standards, did not sell in a market with predominantly down-to-earth customers. The elevator company SCHINDLER integrated a leading architect in the development of a breakthrough development, the Schindler Mobile, a self-propelling cabin that no longer needs machine rooms, thus saving space and reducing process costs. However, in considering only the architect's point of view, the company overlooked the fact that most elevators are ordered after shafts and machine rooms have been built. To most of their customers saving space was therefore not an innovative asset, among them maintenance people and end users. The integrated architect's view led to the elevator's temporary withdrawal from the market.

To reduce this negative side effect, which mostly occurs in the first three innovation sub-phases, a mix of integrated customers, representing different tastes and needs in the market, is the measure of choice.

Customers' specific interests may also cause problems. Having to invest considerable time, customers often agree to the integration only because they expect a personal benefit 
(von Hippel, 1986). If they, correctly or not, perceive a clash of interests between the company and themselves, they will most likely act in their own best interest. This was experienced by SEFAR: on presenting their breakthrough idea of enzyme immobilisation on fabrics to an integration candidate who produces enzymes and related instruments, they were told that the idea was uninteresting. The new idea would have resulted in the customer's instruments becoming obsolete.

This widespread mind set often prevents innovative ideas that, if carried out, would interfere with a customer's own line of production. The side effect of 'losing' possible innovations for this reason mostly appears during opportunity identification and idea generation, but to a lesser degree also in the respective selection phases. Avoiding the integration of only a small number of customers can reduce this risk. A mix of customers from different backgrounds and with different needs counterbalances a particular customer's conscious or subconscious efforts to give the search for ideas a certain direction.

\subsubsection{Serving a niche market only}

A customer's willingness to be integrated is often based on his need for a product adapted to his particular demands. The advantage of this individual wish is that such customers constitute a reliable buyer potential for products that were designed according to their needs (Prahalad and Ramaswamy, 2000). This advantage turns into a disadvantage when it becomes apparent that the customers, representing only a small group, are the only ones interested in the new product. With few exceptions, a mere niche market will hardly meet the company's expectations regarding sales and profit.

Serving a niche market only may occur in all sub-phases with the exception of prototype testing, where the particular wishes are unlikely to be uttered or considered, and should be counteracted unless the niche provides a comfortable return. The implementation of customer integration in two or three separate stages of the innovation phase is recommended, using different customers in each: at the very beginning, in an advanced stage, and for prototype testing. Different prospective buyer groups can then be considered which should prevent the creation of a niche product.

\subsubsection{Dependence on customers' experience}

Customers helping with the innovation process often rely on their experiences, which is why they were chosen in the first place (von Hippel, 1988). They have first-hand knowledge of an existing product and know where it does not fulfil their needs and expectations. There is, however, the risk that they direct their innovative efforts in one direction only: to improve the familiar product rather than to create a radically new solution. Especially with reference customers, this 'functional fixedness', as it is termed, (Leonard, 2002; von Hippel, 1986) tends to prevent radical innovations and encourage incremental ones. The most effective way of excluding, or at least minimising, this side effect (which is most likely to occur in the first three sub-phases) is to integrate lead users rather than reference customers. In addition, the investigated companies recommend relying on 'indirect' customers (e.g., soccer coaches with regard to sportswear) in combination with other integrated customers. SULZER HEXIS, a producer of fuel cells, includes electricians into the innovation process. They gather knowledge about the end consumers' needs and wishes in the course of their every day 
work at consumers' homes. Being experts themselves, the electricians can pass on their customers' experiences without being hampered by the latter group's 'functional fixedness'.

Whenever it is deemed appropriate to integrate demanding and reference customers, the risk of mere incremental innovations can be reduced by way of large numbers. The potentially incremental inclinations of unknown users can be compensated with special toolkits by prioritising the various suggestions and blending them with the lead users' or own experts' ideas.

Finally, incremental innovations can be avoided by an intelligent timing of customer integration. Early customer involvement offers opportunities to counterbalance limited views at later stages and with different knowledge sources.

\subsubsection{Dependence on customers' behaviour/personality}

Sometimes customers demand exclusive rights to the outcome of the combined innovative effort. Apart from the arising problem of intellectual property rights, which will be discussed later, this request, if granted, may impair the success of innovative activities from the very beginning. Only if the customer is the company's biggest or only buyer of the existing products, such a demand would make sense: in this case, the company gets a reliable future first buyer and need not look for others. In all other cases, however, such a restriction would hinder the company from selling the innovation to other customers, thus preventing possibilities of profit.

The request for exclusive rights may turn up in all phases of customer integration, but is more likely in the earlier ones. The obvious way to avoid its negative consequence is to repudiate any demands for exclusivity, looking for other customers instead. Integrating customers who can provide the necessary knowledge without having sufficient market position to demand exclusive rights is the measure of choice. SULZER HEXIS integrates customers from small, independent service companies rather than from the big energy companies that would only cooperate as exclusive partners.

Negative side effects may also occur due to a customer's personality. A group of overly cautious people will not come up with a radical innovation, while a group of visionaries may overlook important details in the innovation process, and so on.

To minimise the possible limitations of the innovative result caused by customers' personal traits, it is advisable to fall back on the findings of ergonomics, because this science has established the importance of recognising and making use of the different roles employees may play: controller, doer, agitator, visionary, or doubter (Margerison and McCann, 1984). These findings also apply to (individual) integrated customers. If the company is familiar with them from former projects, their roles should be taken into account when setting up workshops to guarantee a mix of different role-players among both the internal participants and the customers.

Apart from the scientific findings, the investigated companies reported that unfavourable impressions of co-members in mixed workshops could ruin the atmosphere for the whole integration project. If such an aversion is detected among participants, a face-saving switch of workshop members should be attempted.

Negative side effects due to customers' personal attributes are relevant in all phases with integration in workshops, which excludes prototype testing. 


\subsubsection{Loss of know-how}

A customer who takes part in the innovation process unavoidably acquires company know-how while contributing his own knowledge or ideas ( $\mathrm{Li}$ and Calantone, 1998; Lukas and Ferrell, 2000). If he uses company know-how for his own purposes, this may not be much of a problem, but if he passes it on to a competitor, the consequences may be disastrous. SIG allCap integrated a customer in the early innovation phase who, after jointly generating and developing a concept for innovative packing solutions, took the combined know-how elsewhere. He developed the final product with a competitor, thus increasing the competitor's innovative power to SIG allCap's detriment.

The core of this problem is the question of who owns the results of the combined innovative efforts: the company, the customer, or both (Brouwer and Kleinknecht, 1999; Hagedoorn and Cloodt, 2003; Masurel, 2002). The answer is even more complicated when a customer claims to have contributed know-how that had already existed within the company (so-called contamination with customer know-how).

Conflicts can be avoided by specific agreements on intellectual property rights. Such written contracts should include non-disclosure agreements, detailed lists of who contributes which know-how, and agreements on the ownership of the innovative results. It requires both legal skill and managerial feeling to strike the right balance between the protection of company know-how and the necessary space for creative work in the course of the innovation process. Such a balance can be achieved more easily if the different agreements are drawn up specifically for each sub-phase. Furthermore, all agreements should be signed before integrating customers. Irrespective of the sub-phase, this is an absolute must for non-disclosure agreements.

The best agreements are of little or no use if a customer does not honour them. With regard to the protection of intellectual property, the choice of the right customer means the choice of an honest and trustworthy one. Customers with long-standing contacts or who were reliable in prior minor projects are the best integration candidates.

The choice of the right integration moment also helps prevent a loss of know-how. Customers ought to be integrated as early as necessary, but as late as possible. The customer thus contributes his ideas when they still have a considerable leverage while learning as little as possible about company know-how.

For all negative side effects described earlier, there are specific measures to reduce them. On looking closely at these measures, one will find that they all more or less revolve around the integrated customer. The first and foremost risk-reducing measure therefore is to choose the right customer for the particular integration project, which means looking for competent, experienced, and trustworthy ones.

Another generally valid measure is to consider beforehand if the envisaged project is suitable to customer integration in the first place. Not all projects are, which may be due to the subject or the involved company staff.

Table 2 summarise the findings on each sub-phase with regard to its characteristics, main integration methods, possible negative side effects, and the respective reducing measures. 
Table 2 Summary of sub-phase, integration methods, effects, and risk-reducing measures

\begin{tabular}{|c|c|}
\hline \multicolumn{2}{|c|}{ Characteristics of opportunity identification and analysis } \\
\hline \multicolumn{2}{|c|}{ Searching and evaluating new business fields with the tools of business / technology intelligence } \\
\hline Recommended ways of customer integration & Negative side effects \\
\hline $\begin{array}{l}\text { Normal and lead users via intermediaries } \\
\text { (e.g., key account managers) }\end{array}$ & Dependence on customers' views/interests \\
\hline Normal customers by empathic design & Serving a niche market only \\
\hline Normal and lead users via IT-based tools & Dependence on customers' experience \\
\hline \multirow{2}{*}{$\begin{array}{l}\text { Lead users in workshops and multifunctional } \\
\text { teams }\end{array}$} & Dependence on customers' behaviour/personality \\
\hline & Loss of know-how \\
\hline \multicolumn{2}{|c|}{ Recommended measures for reducing negative side effects } \\
\hline \multicolumn{2}{|l|}{ Careful customer selection } \\
\hline \multicolumn{2}{|l|}{ Mix of customers } \\
\hline \multicolumn{2}{|l|}{ Big numbers } \\
\hline \multicolumn{2}{|l|}{ Good timing } \\
\hline \multicolumn{2}{|l|}{ Scientific findings of ergonomics } \\
\hline \multicolumn{2}{|l|}{ Intellectual property agreements } \\
\hline Scrutinising the project's integration suitabilit & \\
\hline
\end{tabular}

Characteristics of idea and knowledge creation

Generating ideas while gathering new and falling back on existing knowledge

Recommended ways of customer integration Negative side effects

Lead users in creativity and brainstorming Dependence on customers' views/interests workshops

Web-based data banks with links to customers

Serving a niche market only

Toolkits

Dependence on customers' experience

Lead users as managers of core technologies

Dependence on customers' behaviour/personality

Indirect users

Loss of know-how

Recommended measures for reducing negative side effects

Careful customer selection

Mix of customers

Big numbers

Good timing

Scientific findings of ergonomics

Intellectual property agreements

Scrutinising the project's integration suitability 
Table 2 Summary of sub-phase, integration methods, effects, and risk-reducing measures

\begin{tabular}{ll}
\hline Characteristics of prototype testing & \\
\hline $\begin{array}{l}\text { Testing a model to find out if the new ideas work in practice } \\
\text { Recommended ways of customer integration }\end{array}$ & Negative side effects \\
\hline $\begin{array}{ll}\text { Prototype testing by lead users, prospective first } \\
\text { buyers, and reference customers }\end{array}$ & $\begin{array}{l}\text { Dependence on customers' } \\
\text { behaviour/personality } \\
\text { Loss of know-how }\end{array}$ \\
Recommended measures for reducing negative side effects \\
\hline $\begin{array}{l}\text { Careful customer selection } \\
\text { Good timing }\end{array}$ \\
$\begin{array}{ll}\text { Scientific findings of ergonomics } \\
\text { Intellectual property agreements }\end{array}$ \\
Scrutinising the project's integration suitability
\end{tabular}

Characteristics of concept definition

Drawing up a business or technology proposition for the envisaged product

Recommended ways of customer integration Negative side effects

Normally without customers Serving a niche market only

Workshops with lead users, first buyers or Dependence on customers' behaviour/personality

reference customers

Loss of know-how

Recommended measures for reducing negative side effects

Careful customer selection

Mix of customers

Big numbers

Good timing

Scientific findings of ergonomics

Intellectual property agreements

Scrutinising the project's integration suitability

Characteristics of prototype testing

Testing a model to find out if the new ideas work in practice

Recommended ways of customer integration Negative side effects

Prototype testing by lead users, prospective first Dependence on customers'

buyers, and reference customers behaviour/personality

Loss of know-how

Recommended measures for reducing negative side effects

Careful customer selection

Good timing

Scientific findings of ergonomics

Intellectual property agreements

Scrutinising the project's integration suitability 


\section{Discussion and implications}

The paper has introduced a novel concept of the early innovation phase. On the basis of Koen's et al. (2001) NCD model, the early innovation phase is subdivided into five interacting sub-phases that serve as reference frame for the subsequent investigation of customer integration and its negative side effects. This concept, still a theoretical one, will have to be validated in practice; the empirical research, giving the impulse for this paper, was focused on side effects of customer integration rather than on process structures. Whatever the outcome of such future investigation will be, the basic theoretical deductions and empirical statements in this paper concerning side effects will still be valid, applying to similar models as well. The reason for this general applicability is the novel approach to customer integration. So far, theoretical and empirical research has mostly centred on various aspects of customer integration with regard to the early innovation phase as a whole without differentiating between sub-phases of whichever kind; integration methods, the type of customers to be integrated, and negative side effects have been discussed in the general context of the fuzzy front end only. The authors investigated these issues taking the various sub-phases with partly very different needs and aims into consideration. The result consists in detailed, 'customised' recommendations for integration activities in the particular sub-phases.

The main focus is on the negative side effects, also known as risks, of customer integration. Its positive effects, or benefits, are established by now, throwing a rather too glowing light on this widely recommended concept. This paper has gathered theoretical and empirical insights on the often underestimated or even unknown side effects, thus trying to impart a more realistic view of customer integration.

Among the negative side effects predominant in practical customer integration are the dependence on customers and the threat to company know-how. Figure 2 summarises the possible negative side effects of customer integration and their relevance to the different sub-phases of the early innovation phase (the length of each bar illustrates in which sub-phases the respective risk is most likely to turn up):

Figure 2 Negative side effects in the sub phases of the fuzzy front end (see online version for colours)

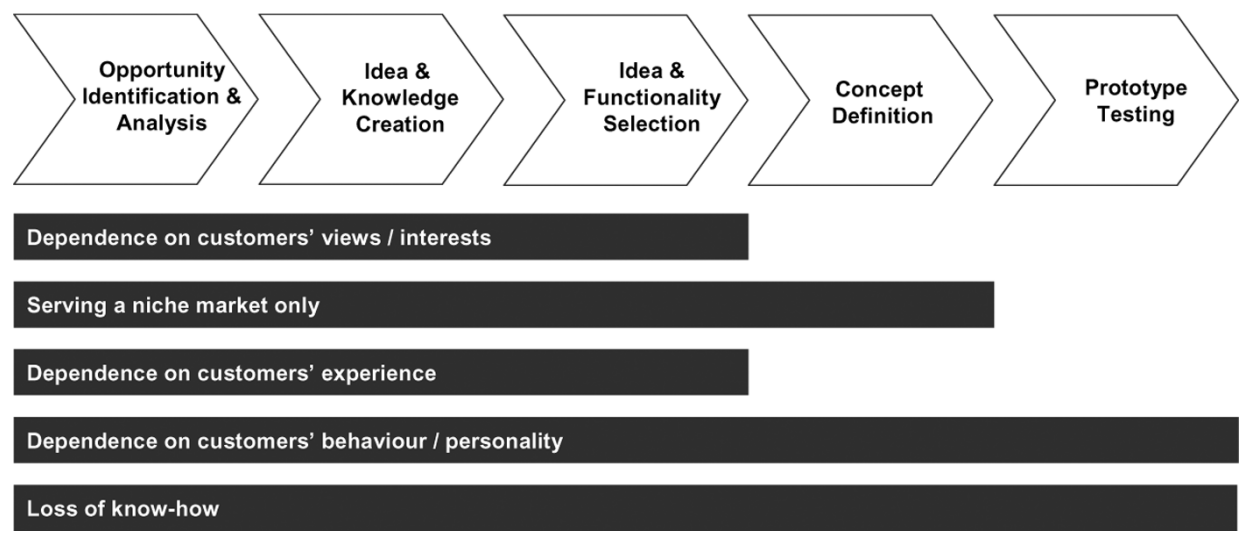

However, it was not the authors' intention to deter managers from integrating customers. On the contrary, another focus was the reduction or even elimination of negative side 
effects. With the detailed description of risk-reducing measures and by giving examples of companies having successfully adopted them, it was shown that side effects are likely to occur but need not have an unduly negative impact because they can be influenced.

To avoid or at least mitigate negative aspects, managers have special measures at their disposal. The customer-related measures comprise the careful selection of customers to be integrated, the right mix of customers within each innovation project, the choice of the best time and place for integration, and the use of appropriate integration methods. With regard to know-how, the provision of effective intellectual property agreements and the selection of trustworthy customers are essential. Company-related problems are reduced by the scrutiny of each innovation project regarding its suitability for integration.

In summary, our empirical research supported the existence of negative side effects while confirming the possibility of their reduction. This has validated our hypothesis, but with a slight modification:

\subsection{Customer integration may, but need not have negative side effects}

This finding, while taking away some of the alleged splendour of customer integration, still makes it an option to be considered.

Managerial implications are obvious: each innovation manager should consider carefully if he ought to integrate customers or not, because the negative side effects may be stronger than the expected positive effects. Secondly, in case he opts for customer integration, he absolutely should adopt measures to reduce or eliminate negative side effects.

As for scientific implications, a comprehensive balance of the positive and negative effects of customer integration, taking into account risk-reducing measures, would be useful. Such a balance ought to include further research on the novel concept of the early innovation phase, testing its general applicability and suitability to the concept of customer integration.

\section{References}

Altshuller, G. (1988) Creativity as an Exact Science: The Theory of Inventive Problem Solving, Gordon and Breach, New York.

Atuahene-Gima, K. (1995) 'An exploratory analysis of the impact of market orientation on new product performance: a contingency approach', Journal of Product Innovation Management, Vol. 12, No. 4, pp.275-293.

Bacon, G. and Beckman, S. (1994) 'Managing product definition in high-technology industries: a pilot study', California Management Review, Vol. 36, No. 3, pp.32-56.

Brockhoff, K. (2003) 'Customers' perspectives of involvement in new product development', International Journal of Technology Management, Vol. 26, Nos. 5-6, pp.464-481.

Brouwer, E. and Kleinknecht, A. (1999) 'Innovative output, and a firm's propensity to patent: an exploration of CIS micro data', Research Policy, Vol. 28, No. 6, pp.615-624.

Bruseberg, A. and McDonagh-Philp, D. (2002) 'Focus groups to support the industrial/product designer: a review based on current literature and designers' feedback', Applied Ergonomics, Vol. 33, No. 1, pp.27-38.

Buggie, F.D. (2002) 'Set the 'fuzzy front end' in concrete', Research Technology Management, Vol. 45, No. 4, pp.11-14. 
Calder, B.J. (1977) 'Focus groups and the nature of qualitative marketing research', Journal of Marketing Research (JMR), Vol. 14, No. 3, pp.353-364.

Cooper, R.G. and Kleinschmidt, E.J. (1986) 'An investigation into the new product process: Steps, deficiencies, and impact', Journal of Product Innovation Management, Vol. 3, No. 2, pp.71-85.

Cooper, R.G. and Kleinschmidt, E.J. (1994) 'Screening new products for potential winners', Institute of Electrical and Electronics Engineers IEE, Engineering Management Review, Vol. 22, No. 4, pp.24-30.

Dahan, E. and Hauser, J.R. (2001) 'Product development - managing a dispersed process', in Weitz, B.A. and Wensley, R. (Eds.): Handbook of Marketing, Sage, London, pp.179-222.

Dwyer, L. and Mellor, R. (1991) 'Organizational environment, new product process activities, and project outcomes', Journal of Product Innovation Management, Vol. 8, No. 1, pp.39-48.

Enkel, E., Kausch, C. and Gassmann, O. (2005) 'Managing the risk of customer integration', European Management Journal, Vol. 23, No. 2, pp.203-213.

Franke, N. and Piller, F. (2004) 'Toolkits for user innovation and design: exploring user interaction and value creation in the watch market', Journal of Product Innovation Management, Vol. 21, No. 6, pp.401-415.

Franke, N. and von Hippel, E. (2002) Satisfying Heterogenous User Needs via Innovation Toolkits: The Case of Apache Security Software, \# 4341-02, MIT Sloan School of Management, Cambridge, MA, pp.1-32.

Gassmann, O. and Enkel, E. (2004) Towards a Theory of Open Innovation: Three Core Process Archetypes, R\&D Management Conference (RADMA), Lisbon, Portugal.

Gruner, K.E. and Homburg, C. (2000) 'Does customer interaction enhance new product success?', Journal of Business Research, Vol. 49, No. 1, pp.1-14.

Hagedoorn, J. and Cloodt, M. (2003) 'Measuring innovative performance: Is there an advantage in using multiple indicators?', Research Policy, Vol. 32, No. 8, pp.1365-1379.

Hart, S., Jan Hultink, E., Tzokas, N. and Commandeur, H.R. (2003) 'Industrial companies' evaluation criteria in new product development gates', Journal of Product Innovation Management, Vol. 20, No. 1, pp.22-36.

Herstatt, C. and von Hippel, E. (1992) 'From experience: developing new product concepts via the lead user method: a case study in a 'low-tech' field', Journal of Product Innovation Management, Vol. 9, No. 3, pp.213-221.

Khurana, A. and Rosenthal, S.R. (1997) 'Integrating the fuzzy front end of new product development', Sloan Management Review, Vol. 38, No. 2, pp.103-120.

Kim, J. and Wilemon, D. (2002) 'Focusing the fuzzy front-end in new product development', $R \& D$ Management, Vol. 32, No. 4, pp.269-279.

Koen, P., Ajamian, G., Burkart, R., Clamen, A., Davidson, J., D’Amore, R., Elkins, C., Herald, K., Incorvia, M., Johnson, A., Karol, R., Seibert, R., Slavejkov, A. and Wagner, K. (2001) 'Providing clarity and a common language to the 'fuzzy front end', Research Technology Management, Vol. 44, No. 2, pp.46-55.

Koen, P., Ajamian, G.M., Boyce, S., Clamen, A., Fisher, E., Fountoulakis, S., Johnson, A., Puri, P. and Seibert, R. (2002) 'Fuzzy front end: effective methods, tools, and techniques', in Belliveau, P., Griffin, A. and Somermeyer, S. (Eds.): PDMA Toolbook for New Product Development, John Wiley and Sons, New York, pp.5-36.

Kohli, A.K. and Jaworski, B.J. (1990) 'Market orientation: the construct, research propositions, and managerial implications', Journal of Marketing, Vol. 54, No. 2, pp.1-18.

Larson, C.F. (2001) 'Management for the new millenium - the challenge of change', Research Technology Management, Vol. 44, No. 6, pp.10-12.

Leonard, D. (1995) Wellsprings of Knowledge: Building and Sustaining the Sources of Innovation, Harvard Business School Press, Boaton, Massachusetts. 
Leonard, D. (2002) 'The limitations of listening', Harvard Business Review, Vol. 80, No. 1, p.93.

Leonard, D. and Rayport, J.F. (1997) 'Spark innovation through empathic design', Harvard Business Review, Vol. 75, No. 6, pp.102-108.

Leonard, D. and Sensiper, S. (1998) 'The role of tacit knowledge in group innovation', California Management Review, Vol. 40, No. 3, pp.112-132.

Li, T. and Calantone, R.J. (1998) 'The impact of market knowledge competence on new product advantage: conceptualization and empirical examination', Journal of Marketing, Vol. 62, No. 4, pp.13-29.

Lilien, G.L., Morrison, P.D., Searls, K., Sonnack, M. and Von Hippel, E. (2002) 'Performance assessment of the lead user idea-generation process for new product development', Management Science, Vol. 48, No. 8, pp.1042-1059.

Linton, J.D., Walsh, S.T. and Morabito, J. (2002) 'Analysis, ranking and selection of R\&D projects in a portfolio', $R \& D$ Management, Vol. 32, No. 2, pp.139-148.

Lukas, B.A. and Ferrell, O.C. (2000) 'The effect of market orientation on product innovation', Journal of the Academy of Marketing Science, Vol. 28, No. 2, pp.239-247.

Margerison, C. and McCann, D. (1984) 'Team mapping: a new approach to managerial leadership', Journal of European Industrial Training, Vol. 8, No. 1, pp.12-16.

Masurel, E. (2002) 'Patenting behaviour by SMEs', International Journal of Entrepreneurship and Innovation Management, Vol. 2, No. 6, pp.574-583.

McGuiness, N.W. and Conway, A.H. (1989) 'Managing the search for new product concepts: a strategic approach', R\&D Management, Vol. 19, No. 3, pp.297-308.

McQuarrie, E.F. and McIntyre, S.H. (1986) 'Focus groups and the development of new products by technologically driven companies: some guidelines', Journal of Product Innovation Management, Vol. 3, No. 1, pp.40-47.

Meade, L.M. and Presley, A. (2002) 'R\&D project selection using the analytic network process', IEEE Transactions on Engineering Management, Vol. 49, No. 1, pp.59-66.

Murphy, S.A. and Kumar, V. (1996) 'The role of predevelopment activities and firm attributes in new product success', Technovation, Vol. 16, No. 8, pp.431-449.

Murphy, S.A. and Kumar, V. (1997) 'The front end of new product development: a Canadian survey', $R \& D$ Management, Vol. 27, No. 1, pp.5-15.

Olson, E.L. and Bakke, G. (2001) 'Implementing the lead user method in a high technology firm: a longitudinal study of intentions versus actions', Journal of Product Innovation Management, Vol. 18, No. 6, pp.388-395.

Prahalad, C.K. and Ramaswamy, V. (2000) 'Co-opting customer competence', Harvard Business Review, Vol. 78, No. 1, pp.79-87.

Thomke, S. and von Hippel, E. (2002) 'Customers as innovators: a new way to create value', Harvard Business Review, Vol. 80, No. 4, pp.74-81.

Tidd, J. and Bodley, K. (2002) 'The influence of project novelty on the new product development process', R\&D Management, Vol. 32, No. 2, pp.127-138.

Ulwick, A.W. (2002) 'Turn customer input into innovation', Harvard Business Review, Vol. 80, No. 1, pp.91-98.

Urban, G.L. and von Hippel, E. (1988) 'Lead user analyses for the development of new industrial products', Management Science, Vol. 34, No. 5, pp.569-582.

Veryzer, R.W. (1998) 'Key factors affecting customer evaluation of discontinuous new products', Journal of Product Innovation Management, Vol. 15, No. 2, pp.136-150.

von Hippel, E. (1986) 'Lead users: a source of novel product concepts', Management Science, Vol. 32, No. 7, pp.791-805.

von Hippel, E. (1988) The Sources of Innovation, Oxford University Press, New York. 